\title{
SUSTAINABILITY AND DESTINATION MANAGEMENT FROM CZECH PERSPECTIVES
}

\author{
Andrea HOLEŠINSKÁ \\ Masaryk University, Faculty of Economics and Administration
}

\begin{abstract}
The aim of destination management is to deploy resources to be competitive, and to steward destination resources to be sustainable (Ritchie \& Crouch, 2006). The former is about the ability to compete in the tourism market, and the latter is about the ability to maintain the quality of physical, social, cultural, and environmental resources while competing in the tourism market. Mowforth and Munt (2009) present key techniques in sustainable tourism, e.g. environmental impact assessment, carrying capacity calculations, limits of acceptable change, area protection or visitor management techniques. Concerning sustainable tourism, further technique is the elimination of negative externalities through their internationalization (Bieger, 2000). Nevertheless, the fundamental tool of destination management is the strategy of sustainable tourism development. This paper focuses on the application of the above mentioned techniques for managing sustainability in the Czech practice. The research identifies the most used techniques with respect to the impacts induced by tourism development in the destination. Moreover, the research reveals the obstacles to applying certain techniques.

Purpose: The reason for running the research is to discover to what extent the Czech destination management organisations (DMOs) reflect sustainability in their destination management. Thus, the research converges to the application of techniques and tools available to sustainable tourism development in practice.

Design/methodology/approach: To demonstrate the diversity of tourism impacts on environment, the sample of the research includes the Czech DMOs that are located in different types of destinations (urban, mountain, rural). Questionnaires are used for collecting data. Firstly, DMOs assess the social, economic and environmental impacts that occur in their destination. Then they identify these techniques and tools that they apply to eliminate the impacts. And furthermore, DMOs state the reason why they do not use a certain technique or tool. The gathered data are processed by statistical methods.

Findings: The key finding is that the most used visitor management technique is information signing. Development strategy and monitoring of customers' satisfaction are done in partnership. A positive result is that DMOs are willing to cooperate with impacts initiators to improve the situation in the destination. The major obstacle is the lack of financial resources for applying certain techniques. DMOs also argue that there is strong unwillingness of entrepreneurs to participate in sustainable tourism development.

Research limitations: The results can be influenced by the subjective perception of the DMOs representatives when assessing destination impacts and used techniques for managing sustainability in their destination. Another limitation is timing. The results demonstrate the situation before the COVID-19 pandemic.

Practical implications: Regardless of the COVID-19 pandemic, DMOs can take advantage of the research to update their destination strategies and improve their development processes. Moreover, tourism policy authorities can consider the identified obstacles to the application of a certain technique in their planning process and their incentives.
\end{abstract}

Key words: destination management, impacts of tourism, managing techniques in sustainable tourism, sustainable development

https://doi.org/10.11118/978-80-7509-820-7-0424 


\section{Introduction}

The issue of sustainability in the context of destination management has been discussed for many years. Ritchie and Crouch (2006) point out that both competitiveness and sustainability are important for destination management.

Practice shows that knowing the concept of sustainability is one thing and applying it is another. In most cases, it is a concept "on paper". What is missing is an awareness of the seriousness of the situation. In doing so, destinations face various economic, socio-cultural, and environmental influences linked to the implementation and development of tourism. In particular, the COVID-19 pandemic showed how some destinations were overburdened by tourism (e.g. urban destinations - cities) and, on the contrary, rural destinations, due to limited cross-border movement of people, started to be sought after and enormously burdened during the COVID-19 pandemic. The awareness of such situation is the first step towards putting the issue of sustainability on the agenda, however the action is essential.

It is therefore appropriate to use various methods and techniques of sustainable tourism to address the negative impacts of tourism. Some authors (Hall \& Page, 2006; Ritchie \& Crouch, 2006) call for an integrated approach to managing resources in a destination. Therefore, it is the task of destination management to consider this into its process.

This article aims to map the situation of managing sustainability in destinations in the Czech Republic. The reason for conducting this research is to discover to what extent the Czech destination management organisations (DMOs) reflect sustainability in their destination management. The research thus converges on the application of techniques and methods available for the development of sustainable tourism in practice.

\section{Research Background}

The aim of destination management is to deploy resources to be competitive, and to steward destination resources to be sustainable (Ritchie \& Crouch, 2006). The former is about the ability to compete in the tourism market, and the latter is about the ability to maintain the quality of physical, social, cultural and environmental resources while compete in the tourism market.

The quality of a destination's resources is influenced by tourism-induced activities. According to the DPSIR model (Pásková, 2009), pressure is exerted on resources, which is reflected in the change in their condition. This creates positive and negative impacts in a destination respectively. It is then the responsibility of policy authorities or DMOs to respond.

Concerning destination management, an overview of tourism sustainability tools is provided by Mowforth and Munt (2009) a Shaw and Williams (2002), see Table 1 below. Certain parallels are evident in the authors, e. g. environmental impact assessment, carrying capacity calculations, limits of acceptable change, area protection or visitor management. In general, to maintain the sustainability of 
resources, destination management uses tools for recreation resource management and for visitor management (Laws, 1995).

Table 1. Tools and techniques for managing sustainability

\begin{tabular}{|c|c|c|}
\hline $\begin{array}{l}\text { Mowforth and Munt } \\
(2009 / / 1998)\end{array}$ & $\begin{array}{l}\text { Shaw and Williams } \\
\text { (2002) }\end{array}$ & $\begin{array}{c}\text { Visitor management // } \\
\text { Laws (1995) }\end{array}$ \\
\hline $\begin{array}{l}\text { - Protection of } \\
\text { territory } \\
\text { - Industry regulation } \\
\text { - Visitor Management } \\
\text { - Environmental } \\
\text { Impact Assessment } \\
\text { (EIA) } \\
\text { - Carrying capacity } \\
\text { - Consultation and } \\
\text { participation } \\
\text { techniques } \\
\text { - Codes } \\
\text { - Sustainability } \\
\text { indicators } \\
\text { - Footprinting and } \\
\text { carbon budget } \\
\text { analysis } \\
\text { - Fair trade in tourism }\end{array}$ & $\begin{array}{l}\text { - Environmental } \\
\text { Impact Assessment } \\
\text { (EIA) } \\
\text { - Visitor Management } \\
\text { - Carrying capacity } \\
\text { - Limits of Acceptable } \\
\text { change } \\
\text { - Protection of } \\
\text { territory }\end{array}$ & $\begin{array}{l}\text { - } \text { Monitoring of } \\
\text { - } \text { Monstomer satisfaction } \\
\text { residents satisfaction } \\
\text { - Monitoring of } \\
\text { stakeholder } \\
\text { satisfaction } \\
\text { - Price policy } \\
\text { - Accessible } \\
\text { - management } \\
\text { - Information signing } \\
\text { - Zoning } \\
\text { - Eisitor centres } \\
\text { - Edhic codes } \\
\text { Education programmes }\end{array}$ \\
\hline
\end{tabular}

Tourism is the source of many negative externalities. In this context, Bieger (2000) calls for the internationalization of externalities. Thus, the cooperation with stakeholders is another technique ensuring the sustainability of destination resources. Bieger (2000) distinguishes two types of cooperation. The one considers cooperation with impacts initiators. And the other type includes the cooperation with impacts eliminators.

With regard to tourism planning, the fundamental tool of destination management is the strategy of sustainable tourism development. This strategy is an agenda that should turn words into action. Thus, DMOs show their responsibility for the sustainable way of tourism development in their destination. Mihalić (2016) comes up with a new collocation "responsustable" - to be both responsible and sustainable.

Nevertheless, the complexity in tourism policy (Farsari, Butler, \& Szivas, 2011) and the integrated approach to development (Hall \& Page, 2006) from the perspective of DMOs encourage the sustainability of tourism development in a destination.

The paper deals with the application of the above-mentioned techniques for managing sustainability in the Czech practice. The research identifies (the most) used techniques of sustainable tourism with respect to the impacts induced by tourism development in the destination. Moreover, the paper reveals the obstacles to 
applying certain techniques; comments the findings in the context of the situation in the Czech Republic; and emphasizes the limitations or the potential transformation challenges for tourism policy and/or DMOs.

\section{Methodology}

The research focuses on sustainability and destination management. Tools and techniques of sustainable tourism applied in destination management are the focus of this research. It is a case study of the Czech Republic, mainly based on the quantitative research supplemented by qualitative comments of the Czech DMOs. A questionnaire was used for data collection, which included both open and closed questions. The questionnaire was in electronic form and was distributed via email.

The research was held before the COVID-19 pandemic. At that time, there was an intensive certification of DMOs by the national tourism authority CzechTourism. The number of DMOs was floating. According to a 2014 database (Holešinská, 2019), there were 45 DMOs operating in the Czech Republic. These were contacted. Gradually, the number of DMOs increased to 64. However, new DMOs were not included in the research due to their short time of existence and presumed lack of experience with destination management, more precisely with managing sustainability. DMOs were divided into three groups according to the type of destination that they maintain, such as a urban type, mountain type and rural type. This division enables to demonstrate the diversity of tourism impacts on environment in each type of destination.

The return rate of the questionnaires is $26.67 \%$. Concerning the chosen method of data collection (email), it is the standard rate. Tested data sample includes 5 DMOs - urban destination type, 5 DMOs - mountain destination type, and 2 DMOs - rural destination type.

The questionnaire was formulated with the following research objective: "to identify the most used techniques of sustainable tourism with respect to the impacts induced by tourism development in the destination". Firstly, DMOs assessed the social, economic and environmental impacts that occur in their destination. Then they identified these techniques and tools that they applied to eliminate the impacts. DMOs commented on whether they were actually implementing the technique/tool and whether they were doing so independently or in collaboration. If DMOs do not implement the technique in question. They were simultaneously asked whether they considered to apply the technique in the future or whether they tried but there was some obstacle. And furthermore, DMOs stated the reason why they did not use a certain technique or tool.

The gathered quantitative data were processed by statistical methods. The selfevaluation of tourism impacts in a destination is measured by average and visualized in graphs. Concerning the applied techniques and tools, the correlation was tested to identify whether there was an implication between the assessed impacts and used tools. The qualitative date from the open questions were processed by the interpretative phenomenological analysis to determine the obstacles and comment the results. 


\section{Results and discussion}

\section{Self-evaluation of tourism impacts in a destination}

First, DMOs assessed the economic impacts of tourism in a destination. They commented on employment in tourism, investment in tourism, seasonality, hidden costs, transaction costs and inflation, see Figure 1 below. DMOs in the urban type of destination perceived seasonality $(\mu=4)$ as a key economic impact on the destination. Employment in tourism and investment is also above average. The urban type also experiences inflation, which is logical due to the high concentration of demand in a relatively small area. Transaction costs are rather lower. Hidden costs are below average, which are the lowest of the three destination types, due to the high concentration of infrastructure and services in a small area. In contrast, the highest hidden costs $(\mu=3.4)$ are shown by DMOs of the mountain type. The explanation is that the infrastructure and its capacity in mountain locations is limited by natural conditions, which is why hidden costs are more visible. On the other hand, transaction costs have a low (even compared to other types of destinations) economic impact. Experience shows (Novotná \& Holešinská, 2019) that stakeholders in mountain areas form a stronger cohesive community. The opposite is true for urban and rural type of destinations. Whereas, in rural areas stakeholders are distant from each other not only spatially, but also physically. In urban areas, tourism demand is so high that stakeholders are not forced to collaborate (to fight for customers), and hence minimal transaction costs are incurred in collaborative negotiations.

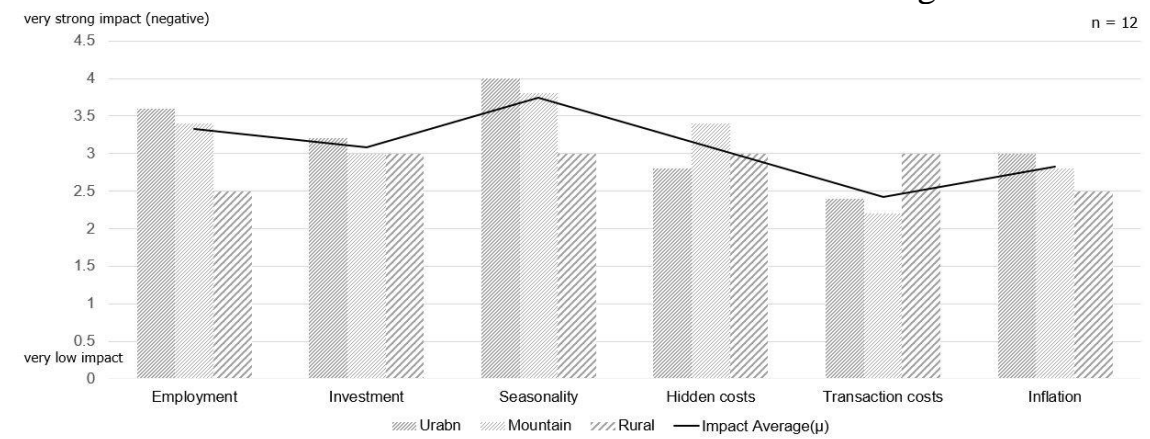

Figure 1. Self-evaluation: Economic impacts of tourism in a destination

Source: Author's own processing

Concerning the social-cultural impacts of tourism in a destination, such as criminality, demonstration effect, marginalization of residents, acculturation, staging, commodification and loss of authenticity (Figure 2), are most evident in the urban type of destinations. Staging dominates $(\mu=3.2)$ - the purposeful display of traditions or customs of the local community. Commodification is another impact that is visible in urban type of destination.

It is worth noting the impact assessment of marginalization of residents, which in the comparison of destinations shows up significantly for the urban type and 
mountain, which is closely related to whether the stakeholder providing the tourism service is also a resident. In the urbanized destinations and most mountain tourist resorts, the owners of key facilities or attractions are not local residents. (Novotná \& Holešinská, 2019) This is also why there are numerous disputes between locals and stakeholders that are not based in the destination.

DMOs belonging to the rural type of destination perceive that the overall sociocultural impacts of tourism to be low. The only impact they feel more strongly than the urban and mountain type of destinations is the demonstration effect, where residents imitate the behaviour of visitors.

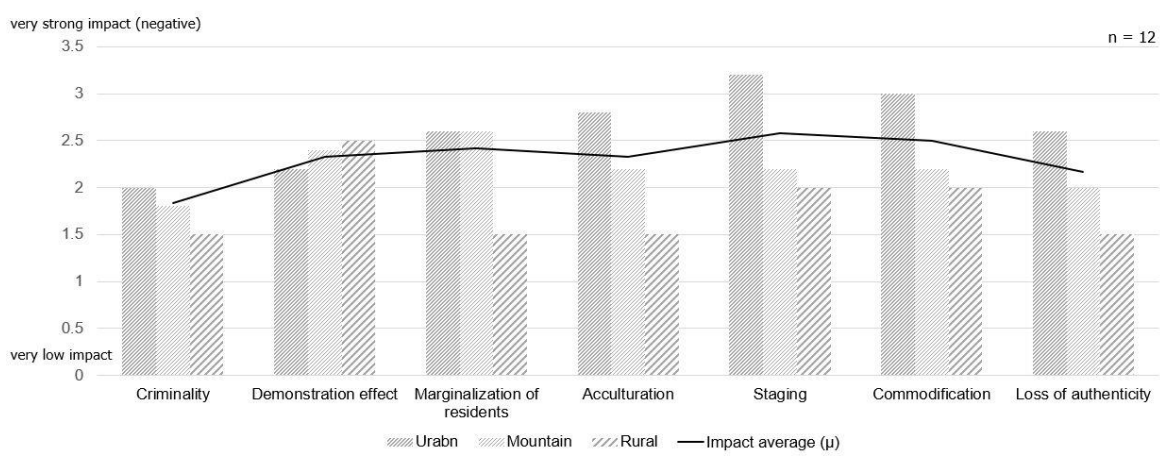

Figure 2. Self-evaluation: Social-cultural impacts of tourism in a destination

Source: Author's own processing

The evaluation of DMOs shows that the environmental impacts of tourism (e.g. pollution, traffic, visual transformation of landscape) are most evident in the mountain type of destinations. At the same time, environmental impacts are lowest in the rural areas (Figure 3).

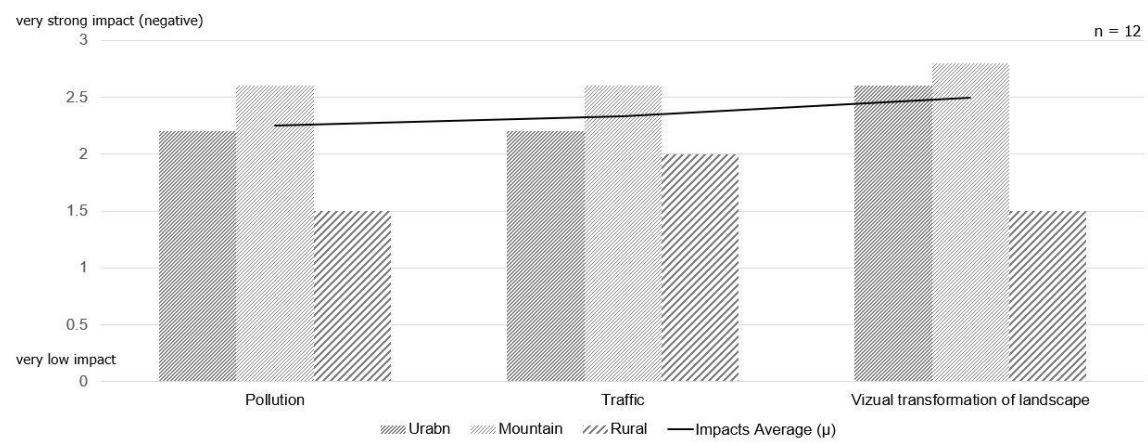

Figure 3. Self-evaluation: Environmental impacts of tourism in a destination

Source: Author's own processing

\section{Applied techniques and tools for managing sustainability}

A key finding was what techniques and tools DMOs used to stimulate sustainable tourism development in a destination, see Figure 4 below. Most DMOs reported 
using information signing. These are mainly the urban and mountain type of destinations. The second most frequently used tool is the development strategy, which half of DMOs are working on. DMOs operating in the mountain areas create their own development strategy. For most DMOs, partnership is important in implementing monitoring of customer satisfaction. Cooperation is also important for DMOs in the case of access management and zoning. In contrast, certification is mostly carried out by DMOs independently.

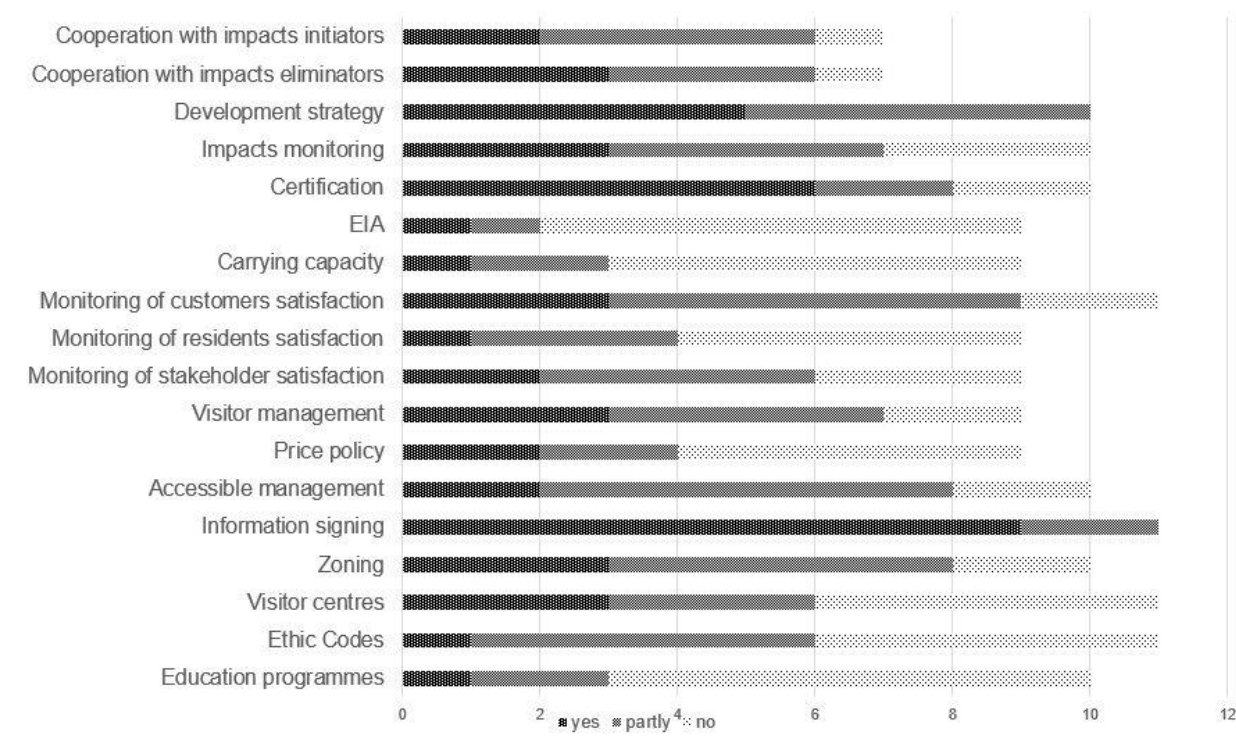

Figure 4. Frequency of used techniques and tools

Source: Author's own processing

More than half of DMOs do not use the EIA (Environmental Impact Assessment) and carrying capacity tool. The lack of experience with these tools is cited as a reason. Half of the DMOs do not use the tools at all to guide visitor behaviour through the Ethic codes and similarly Education programs are not used by DMOs to eliminate (prevent) negative impacts of tourism.

A third of DMOs indicated (especially the urban and mountain type of destinations) that they are willing to work with impact initiators. In general, DMOs from the mountain type of destinations are more willing to apply these tools in destination management. This fact corresponds to some extent with the results of the self-evaluation of impacts.

Unfortunately, the correlation of the individual impacts and the corresponding techniques/tools did not reveal any significant dependence, $r=\langle-0,61 ; 0.69\rangle$. Therefore, it cannot be proved that the identified impacts are the reason for the implemented tools. 


\section{Obstacles for applying techniques}

The major obstacle is the lack of financial resources for applying certain techniques. DMOs also argue that there is strong unwillingness of entrepreneurs to participate in the sustainable tourism development. Especially in the cases of cooperation, both with impacts initiators and with impacts eliminators. One DMO even reported that it had tried to implement monitoring of stakeholder's satisfaction but had encountered reluctance from the stakeholders themselves. This finding is related to trust among stakeholders (Holešinská, 2013; Novotná \& Holešinská, 2019).

One of the other barriers to DMOs not implementing a cooperation strategy to eliminate externalities, is the lack of support from the public sector. In addition to the lack of support for cooperation to eliminate externalities, DMOs reported that they generally lacked the setting of appropriate conditions for DMOs to operate within tourism policy. (Holesinska, 2019)

\section{Conclusion}

Concerning the impacts of tourism in a destination evaluated by DMOs themselves, economic impacts are variable and manifest themselves differently in different types of destinations. In general, seasonality is a key impact. The evaluation showed that socio-cultural impacts were more evident in the urban type of destinations. In contrast, environmental impacts are dominant in the mountain type of destinations. These findings need to be studied and appropriately implemented in strategic planning for sustainable tourism development in the destination.

The research identified the most used techniques of managing sustainability (information signing, development strategy, monitoring of customers satisfaction). Basically, these are visitor management tools. The key is in applying specific partnership techniques. Furthermore, the research found a very low dependency between the variables (impacts and techniques applied). This shows the inconsistency of sustainable development and the weakness of destination management to manage destination resources in a way that is sustainable. Despite the fact that a number of DMOs have indicated their willingness to implement these techniques, there are barriers in the form of lack of financial resources, mistrust among stakeholders and lack of support from tourism policy.

Sustainable tourism development is not the priority for the Czech tourism policy. There is no incentive to support the issue. Therefore, sustainability s up to DMOs themselves. However, they are faced with limited budgets (Holešinská, 2013) and with missing experience in the field of sustainability. If one adds to this the lack of awareness and responsibility from the community perspective, then s/he gets a comprehensive picture of how much the Czech DMOs reflect sustainability in their destination management.

Leaving aside the possibility of bias in the results due to the subjective perception of the DMOs representatives when assessing destination impacts and used techniques for managing sustainability in their destination, as well as due to the 
COVID-19 pandemic, the situation calls for transformation. First of all, the Czech tourism policy needs to change its approach to be complex and to clearly set its priorities. The first priority should therefore be "to be responsible and sustainable" which means to be 'responsustable' (Mihalić, 2016). Hand in hand with this, the Czech DMOs should change the form of traditional patterns in local communities through active communication, education via marketing, active cooperation (projects supporting sustainability). Regardless of the COVID-19 pandemic, DMOs can take advantage of the research to update their destination strategies and improve their development processes. Moreover, tourism policy authorities can consider the identified obstacles to the application of a certain technique in their planning process and their incentives.

The paper was prepared within the Specific Research Project No. MUNI/A/1399/2020 of Masaryk University, Brno, Czech Republic.

\section{References}

1. Bieger T. (2000). Perspektiven der Tourismuspolitik in traditionellen alpinen Tourismusländer - Welche Aufgaben hat der Staat noch?, In ITB-Berlin 2000 „Wissenschaftsforum-Vortrag von Sonntag “. IDT-HSG, St. Gallen.

2. Farsari I., Butler R.W., Szivas E. (2011), Complexity in tourism policies: A Cognitive Mapping Approach, “Annals of Tourism Research", Volume 38, Issue 3, pp. 1110-1134. DOI: https://doi.org/10.1016/j.annals.2011.03.007.

3. Hall M.C., Page S.J. (2006), The geography of tourism and recreation: environment, place and space, Routledge, London.

4. Holešinská A., (2019), Česká podoba konsolidace DMO. In Klímová V., Žítek V. (eds), XXII. mezinárodní kolokvium o regionálních vědách. Sborník přispěvků, pp. 492-499, Masaryk University, Brno. DOI:10.5817/cz.muni.p210-9268-2019-62.

5. Holešinská A. (2013), DMO - A dummy-made organ or a really working destination management organization, "Czech Journal of Tourism", volume 2, number 1, pp. 19-36. DOI:10.2478/cjot-2013-0002.

6. Laws E. (1995), Tourist Destination Management. Issues, Analysis and Policies, Thomson, London.

7. Mihalic T. (2016), Sustainable-responsible tourism discourse - Towards 'responsustable' tourism, "Journal of Cleaner Production", Volume 111, Part B, pp. 461-470. DOI: https://doi.org/10.1016/j.jclepro.2014.12.062.

8. Mowforth M., Munt I. (2009), Tourism and Substainability. Development, globalisation and new tourism in the Third Word, Routledge, Abingdon/New York.

9. Novotná M., Holešinská A. (2019), Behaviour of Stakeholders in Different Destination Networks - Three Cases from the Czech Republic, "Acta Universitatis Agriculturae et Silviculturae Mendelianae Brunensis", volume 67, number 2, pp. 535-544. DOI: 10.11118/actaun201967020535.

10. Pásková M. (2009), Udržitelnost rozvoje cestovního ruchu, Gaudeamus, Hradec Králové.

11. Ritchie J.B, Crouch G.I. (2003), The competitive destination: a sustainable tourism perspective, CABI publishing, Wallingford.

12. Shaw G., Williams A.M. (2002), Critical Issues in Tourism. A Geographical Perspective, Blackwell Publishing, Malden/Oxford/Victoria. 